\title{
The influence of willow plantations and soil composition on the process of natural vegetation settlement at oil drilling sites in Western Siberia
}

\author{
Vladimir N. Sedykh ${ }^{1}$, Vyacheslav V.Tarakanov ${ }^{1 *}$, and Mikhail Yu.Telyatnikov ${ }^{2}$ \\ ${ }^{1}$ West-Siberian Branch of the Sukachev Institute of Forest SB RAS - Branch of the Federal Research \\ Center "Krasnoyarsk Science Center", Zhukovsky Str., 100/1, Novosibirsk, 630082, Russia \\ ${ }^{2}$ Central Siberian Botanical Garden SB RAS of the SB RAS, Zolotodolinskaya Str., 101, Novosibirsk, \\ 630090, Russia
}

\begin{abstract}
Test cultures of various willow species were created in 1997 on a technogenic sandy site of one of oil deposits $\left(62^{\circ} 46^{\prime} 18.36^{\prime \prime} \mathrm{N}\right.$, $72^{\circ} 09^{\prime} 48.69^{\prime \prime}$ E). Sixty-five isolated plots, including various soil substrates (sand, peat, drilling wastes), were placed in the testing area of $684 \mathrm{~m}^{2}$. Optimum combinations of substrate components were identified, and the tolerance of willow species to drilling wastes was revealed by the results of investigating 1-5-year cultures [1]. In 2016 we investigated the natural settlement of aborigine plants in this test plot. The willow cultures mortality was high according to short offspring vegetative lifetimes and the limitation of feed areas. However, willow cultures and soil reclamation stimulated a settlement of natural plant seedlings. The comparison of phytocenoses, which were formed in various experimental and "background" conditions, has allowed making some conclusions. 44 plant species are growing now in the experimental area. The least number of species is characteristic for pure sand and pure peat substrates, the greatest - for complex substrates with sand, peat and drilling wastes. Thus, the experimental willow cultures and partial soil reclamation accelerated the formation process of forest ecosystems that created a "plant oasis" on a deserted landscape of technogenic sand.
\end{abstract}

\section{Introduction}

The north of Western Siberia resembles the arena of continuous "struggle" between forests and marshes [2]. At present, as a result of the activities of the oil and gas complex, drybottom habitats of sand and peat have been created on the site of a significant part of the former wetlands [1]. Gradually, they turn into "man-made" forests. But without human assistance, this process can take several decades [3].

The study of the dynamics of vegetation appearance in the technogenic landscapes of the oil complex shows that, at the initial stage of the forest formation process, the "pioneer"

\footnotetext{
* Corresponding author: tarh012@mail.ru
} 
species of genera Salix, Populus and Betula play an active role. They create a forest environment and contribute to the settlement of other species, including conifers.

With this in mind, the forest reclamation technology, which "launches" the mechanism of the initial stage of forest formation by creating cultures from local willow species [4], has been developed. To study the reaction of these species to peat-sand substrates contaminated with drilling wastes, a test site for forest reclamation was created about 20 years ago [5].

The studies carried out in 1-5 years after plantations allowed for the selection of reclamation- and recultivation-promising willow species and soil compositions, respectively. However, the issue of the extent to which artificial plantations and sand reclamations contribute to the process of natural overgrowing of this experimental area have not yet been studied.

The purpose of this work is to assess the productivity and species diversity of the phytocenosis, which was formed at the experimental site after its recultivation.

\section{Materials and Methods}

The experimental forest reclamation site with the total area of $684 \mathrm{~m}^{2}$ was created on the unexploited sandy part of the well drilling site in the Tyansk (now Muryaunsky) oil field of OJSC "Surgutneftegaz" located on the territory of ridge-bog complex in the middle taiga zone (62 ${ }^{\circ} 4618.36^{\prime \prime}$ n. lt. $72^{\circ} 09^{\prime} 48.69^{\prime \prime}$ e. lng.) during1997-1998. The methodical features of the experiment are described in the monograph [1].

Experimental plots with the total area of $261 \mathrm{~m}^{2}$ included 61 box sections, each with the area of $1 \mathrm{~m}^{2}$ and depth of $0.3 \mathrm{~m}$, as well as 4 micro-grounds, each with the area of $50 \mathrm{~m}^{2}$ and depth of $0.5 \mathrm{~m}$ (Fig. 1). They were intended to study the dose-effect relation in a wide range of ratios of drilling waste, peat and sand, and the concentration of each of which varied from 0 to $80-100 \%$, also for testing various species that are a priori promising for forest reclamation. At the same time, most of the grounds were planted by Salix triandra L., $S$. dasyclados Wimm., S. viminalis L., S. pentandra L. and S. bebbiana Sarg. Also, wild species of Betula pendula Roth., Ehrh ., Sorbus sibirica L., seedlings of Larix sibirica Ledeb. and hybrid forms of the poplar breeding of CSBG SB RAS [6] were planted in small numbers. In addition, Pinus sylvestris L., Larix sibirica Ledeb. and Hippophae rhamnoídes L. seeds were sown in plots of 1-2 $\mathrm{m}^{2}$.

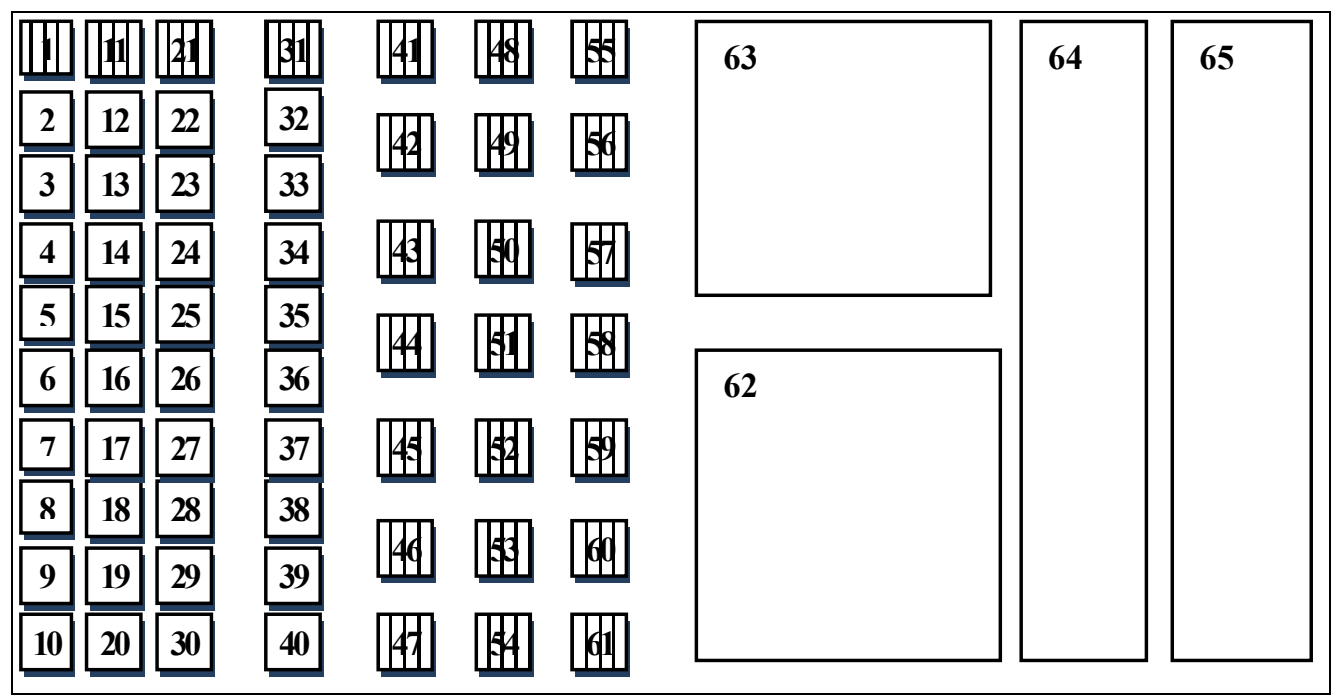


Fig.1. The layout of the plots within the recultivated site. Plots № 1-30 - box sections (each of $1 \mathrm{~m}^{2}$ ) with substrates of sand and drilling waste; No. 31-40 - box sections of $1 \mathrm{~m}^{2}$ with substrates of sand and peat, to which the drilling waste was added in 2004 and which were temporarily used for growing vegetables; No. 41-61 - box sections of $1 \mathrm{~m}^{2}$ with substrates of sand, peat and drilling waste; No. 62 section of $50 \mathrm{~m}^{2}$ with a sand substrate; No. 63 - section of $50 \mathrm{~m}^{2}$ with a substrate of sand and drilling waste; No. 64 - section of $50 \mathrm{~m}^{2}$ with a peat substrate; No. 65 - section of $50 \mathrm{~m}^{2}$ with a substrate of sand and peat.

At the end of August, 2016, in the experimental plots and on the land free from plantations, the list and abundance of plant species and tree-stand taxation parameters were estimated using generally accepted geobotanical and silvicultural methods.

\section{Results and discussion}

In order to create artificial phytocenoses, 12 woody plant species, with over $90 \%$ of the plots occupied by 5 willow species, were involved. Forty-four plant species, unevenly distributed among the experimental variants (Tables 1,2), were found in the recultivated area in twenty years after the planting.

Of these, 5 tree species and 5 willow species were preserved from the original plantation. But if birches and pines increased their share of participation in the phytocenosis due to the growth of saplings and the emergence of self-sowing, the aging willow cultures are at an older age, and their participation in the phytocenoses decreased to $0-38 \%$, being $15 \%$ on the average (Table 3 ). The number of species increased, in comparison with the plantation, by 34 . This was mainly due to the species of herbaceous plants, mosses and shrubs (Table 2).

Table 1. List of plant species found in 2016 within the recultivated area

\begin{tabular}{|c|l|c|}
\hline Storey & \multicolumn{1}{|c|}{ List of plant species } & N \\
\hline Trees & $\begin{array}{l}\text { Larix sibirica, Pinus sylvestris, Populus nigra, P. hybryda, Betula } \\
\text { pendula }\end{array}$ & 5 \\
\hline $\begin{array}{c}\text { Tall } \\
\text { shrubs }\end{array}$ & $\begin{array}{l}\text { Sorbus sibirica, Salix bebbiana, S. dasyclados, S. pentandra, S. triandra, } \\
\text { S. viminalis }\end{array}$ & 6 \\
\hline Shrubs & Betula nana & 1 \\
\hline $\begin{array}{c}\text { Small } \\
\text { shrubs }\end{array}$ & $\begin{array}{l}\text { Empetrum nigrum, Ledum palustre, Vaccinium myrtillus, V. uliginosum, } \\
\text { V. vitis-idaea }\end{array}$ & 5 \\
\hline Herbs & $\begin{array}{l}\text { Calamagrostis langsdorffii, Carex species, C.aquatilis, C. limosa, } \\
\text { Chamaenerion angustifolium, Dactylorhiza fuchsii, Diphasiastrum } \\
\text { complanatum, Drosera rotundifolia, Equisetum arvense, Eriophorum } \\
\text { polystachion, E. vaginatum, Juncus compressus, Oxycoccus palustris, } \\
\text { Poa palustris, Rubus chamaemorus, Stellaria palustris, Trifolium } \\
\text { pratense, Vicia cracca. }\end{array}$ & 18 \\
\hline Mosses & $\begin{array}{l}\text { Aulacomnium turgidum, Sphagnum species, Polytrichum piliferum, P. } \\
\text { strictum, P. species, Pohlia sp., Hypnum mosses }\end{array}$ & 7 \\
\hline Lichens & Cladonia species, C. coccifera & 2 \\
\hline \multicolumn{1}{|c|}{ Total } & 44 \\
\hline
\end{tabular}

Table 2. Number of plant species (psc.) in different recultivated plot variants

\begin{tabular}{|c|c|c|c|c|c|c|c|c|}
\hline \multirow[t]{2}{*}{ Storey } & \multicolumn{3}{|c|}{ Box sections (each of $1 \mathrm{~m}^{2}$ ) } & \multicolumn{4}{|c|}{ Micro-grounds (each of $50 \mathrm{~m}^{2}$ ) } & \multirow{2}{*}{\begin{tabular}{|c|} 
Sand \\
interlocking \\
areas
\end{tabular}} \\
\hline & $\begin{array}{c}\text { S+DW } \\
\text { (№ 1- } \\
30 \text { ) }\end{array}$ & \begin{tabular}{|l|}
$\mathrm{S}+\mathrm{DW}+\mathrm{P}$ \\
(№ 31-40)
\end{tabular} & \begin{tabular}{|l|}
$\mathrm{S}+\mathrm{DW}+\mathrm{P}$ \\
(№ 41-61)
\end{tabular} & $\begin{array}{c}\mathrm{S} \\
\text { (№ 62) }\end{array}$ & $\begin{array}{l}\text { S+DW } \\
\text { (№ 63) }\end{array}$ & $\begin{array}{c}\mathrm{P} \\
\text { (№ 64) }\end{array}$ & $\begin{array}{c}\text { S+P } \\
\text { (№ 65) }\end{array}$ & \\
\hline Trees & 1 & 4 & 3 & 4 & 2 & 1 & 1 & 5 \\
\hline
\end{tabular}




\begin{tabular}{|c|c|c|c|c|c|c|c|c|}
\hline Tall shrubs & 3 & 4 & 4 & 4 & 1 & 0 & 0 & 1 \\
\hline Shrubs & 1 & 1 & 1 & 0 & 1 & 1 & 1 & 0 \\
\hline Small shrubs & 3 & 6 & 3 & 3 & 6 & 5 & 5 & 5 \\
\hline Herbs & 8 & 15 & 11 & 1 & 5 & 5 & 5 & 3 \\
\hline Mosses & 2 & 6 & 6 & 1 & 3 & 2 & 2 & 4 \\
\hline Lichens & 0 & 1 & 2 & 1 & 1 & 0 & 0 & 1 \\
\hline Total & 17 & 36 & 29 & 14 & 18 & 13 & 13 & 19 \\
\hline
\end{tabular}

Note: S, DW, P - sand, drilling waste and peat, respectively.

If we compare different experimental variants with each other, as well as experimental plots with areas free from plantations, we can note the following. The largest number of plant species is in the range of 29-36 pcs., and the largest participation of woody plants with a total projective cover of $37-42 \%$ is characteristic for variants with a complex composition of substrates which include sand, peat and drilling waste (see Table 2-3). At the same time, the variant of temporary use of plots for growing vegetables (sections 31-40) also differs by the maximum number of herbaceous plant species, which could be caused by their additional reclamation (due to the introduction of additional biomass into the soil and its loosening). On the average, the smallest projective cover of $0-28 \%$ vegetation is observed on the sandy ground (landfill) No. 62 and in the sandy areas free from experimental plantations.

Table 3 Total projective cover by plants (\%) in different recultivated plot variants

\begin{tabular}{|c|c|c|c|c|c|c|c|c|}
\hline \multirow[b]{2}{*}{ Storey } & \multicolumn{3}{|c|}{ Box sections (each of $1 \mathrm{~m}^{2}$ ) } & \multicolumn{4}{|c|}{ Micro-grounds (each of $50 \mathrm{~m}^{2}$ ) } & \multirow{2}{*}{$\begin{array}{c}\text { Sand } \\
\text { interlocking } \\
\text { areas }\end{array}$} \\
\hline & $\begin{array}{c}\text { S+DW } \\
\text { (№ 1- } \\
30 \text { ) }\end{array}$ & \begin{tabular}{|l}
$\mathrm{S}+\mathrm{DW}+\mathrm{P}$ \\
$($ № 31-40)
\end{tabular} & \begin{tabular}{|l|}
$\mathrm{S}+\mathrm{DW}+\mathrm{P}$ \\
(№ 41-61)
\end{tabular} & $\begin{array}{c}\mathrm{S} \\
\text { (№ 62) }\end{array}$ & $\begin{array}{l}\text { S+DW } \\
\text { (№ 63) }\end{array}$ & $\begin{array}{c}P \\
\text { (№ 64) }\end{array}$ & $\begin{array}{c}\text { S+P } \\
\text { (№ 65) }\end{array}$ & \\
\hline Trees & 19 & 43 & 37 & 16 & 22 & 15 & 22 & 24 \\
\hline Tall shrubs & 38 & 3 & 28 & 5 & 3 & 0 & 21 & 0 \\
\hline Shrubs & 3 & 2 & 1 & 0 & 2 & 4 & 5 & 0 \\
\hline Small shrubs & 2 & 4 & 3 & 2 & 8 & 11 & 10 & 2 \\
\hline Herbs & 18 & 15 & 11 & 2 & 8 & 13 & 9 & 2 \\
\hline Mosses & 58 & 25 & 29 & 6 & 24 & 52 & 17 & 28 \\
\hline Lichens & 0 & 1 & 1 & 1 & 1 & 0 & 1 & 3 \\
\hline Total & 132 & 61 & 88 & 26 & 61 & 136 & 101 & 36 \\
\hline
\end{tabular}

Note: S, DW, P - sand, drilling waste and peat, respectively.

The integral taxation-botanical characteristics of groups of variants suggests that the amelioration of poor sandy substrates with peats and drilling waste, in combination with woody plantations, first of all willow species, leads to the accelerated formation of closed birch-willow stands with an admixture of conifers (Table 4). Favorable conditions for the formation of tree phytocenoses are also created in the interplot space, where the undergrowth thickness 38 thousand pcs/ha. At the same time, at a distance from the recultivated area, the sandy pad areas are practically not overgrown. 
Table 4. Taxation-botanical characteristics of plantations (phytocenoses) in the recultivated area (RA)

\begin{tabular}{|l|c|c|c|c|c|c|}
\hline $\begin{array}{c}\text { Experimental } \\
\text { variant }\end{array}$ & $\begin{array}{c}\text { Stand } \\
\text { composition }\end{array}$ & $\begin{array}{c}\text { Stand density, } \\
\text { psc/ha. }\end{array}$ & $\begin{array}{c}\text { Stand stock, } \\
\mathrm{m}^{3} / \text { ha. }\end{array}$ & $\begin{array}{c}\text { Undergrowth } \\
\text { density, } \\
\text { th.psc./ha. }\end{array}$ & $\begin{array}{c}\text { Total of plant } \\
\text { species, psc. }\end{array}$ & $\begin{array}{c}\text { Total } \\
\text { projective } \\
\text { cover, \% }\end{array}$ \\
\hline Sections of $1 \mathrm{~m}^{2}$ & 8S2B +P & 16143 & 21 & 49.4 & 31 & 116.0 \\
\hline Sections of $50 \mathrm{~m}^{2}$ & 6B3L1S+P & 12150 & 39 & 29.7 & 31 & 83.8 \\
\hline Interplot areas & 5B3S2P & 7785 & 15 & 38.3 & 21 & 36.1 \\
\hline $\begin{array}{l}\text { Area adjacent to } \\
\text { the RA }\end{array}$ & - & - & - & 11.4 & - & $<5.0$ \\
\hline
\end{tabular}

\section{Conclusions}

Creating cultures of willows and other woody plant species from "pioneer" ones, also the "mosaic" melioration of sands, accelerate the process of oil well drilling sites natural overgrowth in Surgut Woodland. In the future, close species-rich birch-willow stands with an admixture of conifers may form in such areas.

\section{References}

1. M.I. Neyshtadt, Scientific prerequisites of developing swamps of West Siberia (M, Nauka, 1977)

2. V.N. Sedykh, V.V. Tarakanov. Woody plant tolerance to drilling wastes (Ed. Miljutin, 2004)

3. M.N. Gasheva, A.V. Soromotin, S.N. Gashev, Ecology, 2 (1990)

4. Yu.N. Ilichev, V.V. Tarakanov, I.A. Galkin. Forestry, 5 (2002)

5. V.N. Sedykh, V.V. Tarakanov, V.T. Bakulin. Forest science, 3 (2003)

6. V.T. Bakulin. The introduction and breeding of poplar in Siberia (Novosibirsk, 1990) 